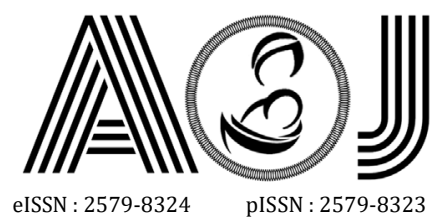

\title{
RESEARCH
}

\section{The Effect of Giving Virgin Coconut Oil (VCO) to Changes in Lauric Acid Levels in Breast Milk}

\author{
Ismul Sadly Putra ${ }^{1}$, Joserizal Serudji ${ }^{2}$, Sumaryati Syukur ${ }^{3}$
}

Affiliation author: 1. Obstetrics and Gynecology, Faculty of Medicine, Andalas University, Dr. M. Djamil Central General Hospital Padang, West Sumatera, Indonesia; 2. Sub Division of Maternal Fetal Medicine, Obstetrics and Gynecology Department, Faculty of Medicine, Andalas University, Dr. M. Djamil Central General Hospital Padang, West Sumatera, Indonesia

Correspondence to: Ismul Sadly Putra, email:neclordboy@gmail.com, Hp: 082386650784

\begin{abstract}
Introduction : Breastmilk is the best food produced by the breast glands, containing all the nutritional elements needed by infants aged 0-6 months. Babies who are not exclusively breastfed will be more susceptible to chronic diseases, such as heart disease, hypertension, and diabetes as adults and can suffer from malnutrition and obesity. Dietary intake significantly affects milk production. Lauric acid contained in breast milk can help your minor fight infection and increase immunity to protect from various diseases. Not only for the baby, but virgin coconut oil is also starting to be commonly used by dieters. Virgin coconut oil contains lauric acid $\mathrm{CH} 3$ (CH2) $10 \mathrm{COOH} \mathrm{50 \%} \mathrm{and} \mathrm{caprylic} \mathrm{acid} \mathrm{CH} 3$ (CH2) $6 \mathrm{COOH} \mathrm{7 \%}$. The benefits of virgin coconut oil (VCO) are that it is beneficial for the health of the body, including being antibacterial, antiviral, anti-fungal, and natural anti-protozoa; helps relieve symptoms and reduces health risks associated with diabetes, helps protect against osteoporosis, helps prevent high blood pressure, helps prevent liver disease, keeps the heart and blood vessels healthy, helps prevent cancer, helps you lose weight, maintain stamina, maintain healthy skin and hair.

Objective : This study compared the result of Lauric Acid in breastmilk from the subjects who take reguler VCO before and after 2 weeks of consumption.

Material and Methods : This is an experimental study on 17 subjects of breastfeeding mother who take reguler VCO. Lauric Acid was examined in their breastmilk before and 2 weeks after reguler take of $V C O$. Statistical analysis to test the significance is done by using T-test.

Result : The average concentration of lauric acid profile after VCO was given was higher, namely 6.6 \pm 2.4 while before $V C O$ was given it was $6.2 \pm 2.2$. The result was statistically significant.

Conclussion : There is a increase of lauric Acid concentration in breastmilk before and 2 weeks after reguler intake of $V C O$.
\end{abstract}

Keywords: Breastmilk, Lauric Acid, VCO

\section{INTRODUCTION}

Breastmilk is the best food produced by the breast glands, it contains all the nutrients needed for babies aged 0-6 months. In addition to nutrients, breast milk also has other non-nutritive components that function as immune factors for babies. Breast milk production is influenced by lactate secretion, storage in the mother's body and the food consumed by the mother, so 


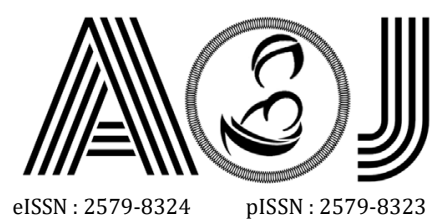

eISSN : 2579-8324
pISSN : 2579-8323

it is very important to pay attention to the intake of breastfeeding mothers so that the milk produced can support the growth and development of children. ${ }^{1,2}$

Breastfeeding provides several benefits for babies, including being able to support the growth and development of babies, containing antibodies that protect babies from bacterial, viral, fungal and parasitic infections, containing the right composition because the content of breast milk is created according to the baby's requirements increasing the baby's intelligence, avoiding from allergies that usually arise due to consumption of formula milk, babies feel their mother's love directly during the breastfeeding process, and when they grow up, they will reduce the risk of developing hypertension, cholesterol, overweight, obesity and type 2 diabetes, vulnerable to chronic diseases, such as heart disease, hypertension, and diabetes as an adult and can suffer from malnutrition and obesity. ${ }^{3}$

So that the benefits of breastfeeding can be obtained by the child as a whole, the quality and quantity of breast milk must be sufficient. To achieve good quality and quantity of breastfeeding, mothers must pay attention to her health and to increase breast milk, mothers must improve the quality of the food they consume. ${ }^{4}$

Dietary intake greatly affects milk production. The mother's diet can affect the composition of her milk through several metabolic pathways, especially the concentration of fatty acids and water-soluble vitamins, including vitamins A, C, B6, and B12. In contrast, the mineral content of breast milk is generally less related to maternal food intake. ${ }^{5}$

Fats in breast milk reach an important position as a source of energy, structural and regulatory functions, where fatty acids are essential for the development of the central nervous system, antiprotozoal activity (free fatty acids produced during digestion of the stomach and intestines). ${ }^{4,5}$

Lauric acid contained in breast milk can help the baby to fight infection and increase immunity so as to avoid being attacked by various diseases. Not only for the baby, virgin coconut oil is also starting to be used by dieters. Lauric acid makes up about $50 \%$ of the fatty acid content of coconut oil; South Asian and Oceanic communities who use coconut oil as their main source of dietary fat tend to be at lower cardiovascular risk. Because ketone bodies can exert neuroprotective effects, moderate ketosis induced by regular consumption of Middle Chain Triglycerides (MCTs) may have neuroprotective potential. Compared to traditional MCTs such as $\mathrm{C} 6-\mathrm{C} 10$, lauric acid tends to produce a lower pattern of elevated blood ketones. ${ }^{6,7}$

Lauric acid, or dodecanoic acid is the main fatty acid in coconut oil and palm kernel oil, and is believed to have antimicrobial properties. Lauric acid is a white solid, powder with a slight bay oil odor. Coconut oil based on its fatty acid content is classified into lauric acid oil, because its lauric acid content is the largest when compared to other fatty acids. ${ }^{8}$ 


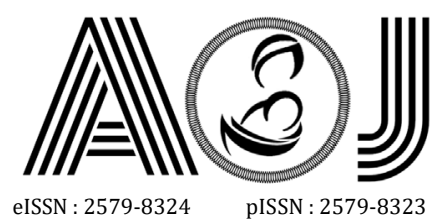

eISSN : 2579-8324
pISSN : 2579-8323

Lauric acid is a saturated fatty acid that is the active ingredient in coconut oil. This fatty acid is a powerful ingredient and is sometimes extracted from coconut to make monolaurin, an agent that has antibacterial, antiviral, and antifungal properties. Coconut oil, being a source of lauric acid, has been linked to several potential health benefits. ${ }^{9}$

This lauric acid molecule is found in coconut meat and most of the lauric acid will be converted into monolaurin which can help increase the body's immunity against bacteria. After that monolaurin will break down into cholesterol. Unlike other saturated fats, the cholesterol raised by lauric acid is HDL cholesterol, not LDL cholesterol, which causes blockage of blood vessels and heart disease. So eating coconuts may reduce the risk of heart disease. ${ }^{10}$

Coconut meat is usually used as two commodities, namely copra and coconut oil. Coconut flesh is extracted from the wet content and leaves the copra after drying. This wet content usually contains a lot of lauric acids and is commonly called coconut oil. Usually, in addition to food and industrial consumption, coconut oil is also used as biodiesel fuel by a process called transesterification in which saturated fats such as lauric acid are converted into esters as a component of biodiesel. ${ }^{11,12}$

Countries in the Southeast Asian region are rich in coconut oil and other coconut byproducts. Coconut oil is the oil extracted from the flesh of ripe coconuts. Coconut oil is widely used during pregnancy in these countries where published studies on the use of herbal remedies during pregnancy have shown that in certain areas about $61 \%$ to $63.9 \%$ of women of childbearing age use coconut oil as herbal medicine. ${ }^{13,14,15}$

Virgin Coconut Oil (VCO) is coconut oil that is obtained from wet processes and without going through chemical refining, where VCO has many benefits for pregnant women, it is obtained an increase in several components of breast milk that are important for babies such as lauric acid. In addition to functioning as a nutrient, lauric acid also functions as an immunomodulator that can protect babies from pathogen attacks. ${ }^{16,17}$

Pure VCO oil is widely used in the pharmaceutical, cosmetic, formula milk industries, as well as high quality cooking oil. Pure VCO oil can overcome various diseases in humans. For the treatment of diseases, pure VCO oil is used to treat HIV-AIDS, cancer, hepatitis, osteoporosis, diabetes, heart disease, obesity, and various diseases caused by microbes. ${ }^{16,17}$

Virgin coconut oil contains lauric acid $\mathrm{CH} 3(\mathrm{CH} 2) 10 \mathrm{COOH} 50 \%$ and caprylic acid $\mathrm{CH} 3(\mathrm{CH} 2) 6 \mathrm{COOH} 7 \%$. Both of these acids are medium chain saturated fatty acids that are easily metabolized and have antimicrobial properties. In the body, lauric acid becomes monolaurin, while caprylic acid becomes monocaprine. Lauric acid has a function, which is converted into monolaurin in the human body. Monolaurin is an antiviral, antibacterial and antiprotozoal monoglyceride that is used by the human and animal immune systems to destroy lipid-protecting viruses, such as HIV, herpes, influenza, and various bacterial pathogens. ${ }^{18,19}$ 


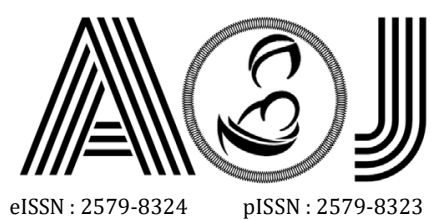

eISSN : 2579-8324
pISSN : 2579-8323

The benefits of virgin coconut oil (VCO) are efficacious for the health of the body, including natural antibacterial, antiviral, antifungal, and antiprotozoal; helps relieve symptoms and reduce health risks associated with diabetes, helps protect against osteoporosis, helps prevent high blood pressure, helps prevent liver disease, keeps heart and blood vessels healthy, helps prevent cancer, helps with weight loss, maintain body stamina, maintain healthy skin and hair. ${ }^{20}$

Because there have not been many studies on the effect of VCO on lauric acid content in breast milk, and the importance of lauric acid in breast milk for infants, the researchers were interested in designing a study entitled The Effect of Giving Virgin Coconut Oil (VCO) to Changes in Lauric Acid Levels in Breast Milk.

\section{METHODS}

This type of research is experimental with a one group pre-posttest design, which is a design used to measure the effect of treatment on the experimental group by looking at the difference in lauric acid results after and before being given treatment. The study was conducted from May 2020 to September 2020. The sample in this study were respondents who gave birth at the Rika Midwife Clinic, Padang city with an age limit of 20-40 years, the sample required for this study amounted to 15 each sample group. This is in accordance with the statement of Ouyang. $R$ in his book about the sample size in research. The anticipated drop out estimate of $10 \% \times 15$ samples $=16.5$ is fulfilled to become 17 samples. Prepared an informed consent form, materials, tools and permits from the research ethics committee and permits from the head of the Obstetrics and Gynecology department of Dr. M. Djamil Padang General Hospital. The selection of respondents was carried out by researchers through inclusion criteria. Respondents are domiciled around Padang city. The subjects selected according to the inclusion criteria were 17 people. 17 subjects will be given VCO regularly. Subjects were asked to be willing to take the first breast milk sample with sterile pumping then copied to a sterile container of $\pm 10 \mathrm{cc}$ and examined in the laboratory. Subjects were given VCO orally for 2 weeks at a dose of $3 \times 1$ tablespoon and followed up once a week so as not to forget consuming it. Subjects were contacted again after being given treatment for 2 weeks. Subjects were taken breast milk again with sterile pumping and put into a sterile container. This sterile breast milk was examined for lauric acid levels by gas chromatography. This sterile breast milk was brought to the UNAND chemical laboratory to be examined for lauric acid levels using the GCMS (Gas Cromatography and Mass Spectroscopy) tool. Data on respondent characteristics and examination results were analyzed univariately where for numerical data in the form of mean values and standard deviations. To determine the effect of VCO on changes in lauric acid levels in breast milk, a dependent t-test (paired t-test) was 


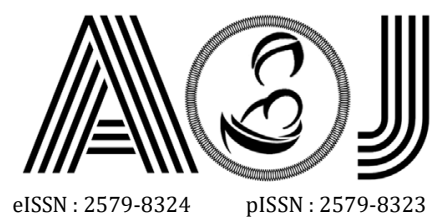

ANDALAS OBSTETRICS AND GYNECOLOGY JOURNAL

Address for Correspondence:

Editorial Room Andalas Obstetrics and Gynecology Journal, $3^{\text {rd }}$ floor of KSM of Obstetrics and Gynecology,

RSUP DR. M. Djamil Padang, Jl. Perintis Kemerdekaan Padang, Sumatera Barat 25127

Website:

http://jurnalobgin.fk.unand.ac.id/index.php/JOE

used with $95 \% \mathrm{Cl}$. If the $p$-value $<0.05$, it can be concluded that result considered statistically significant.

\section{RESULTS}

Research has been conducted on 17 respondents who gave birth at the Rika Midwife Clinic to find out how the relationship between Virgin Coconut Oil (VCO) regular consumption to changes in lauric acid levels in breast milk.

\section{Characteristics of Respondents}

The characteristics of research respondents can be seen in Table 1.1 below:

Table 1. Characteristics of Respondents

\begin{tabular}{|c|c|}
\hline Characteristics & Mean \pm SD \\
\hline Age (years) & $29,9 \pm 4,7$ \\
\hline Parity & $2,7 \pm 0,9$ \\
\hline
\end{tabular}

Based on Table 1, it is known that the average age of the respondents is $29.9 \pm 4.7$ years and the average number of parity is $2.7 \pm 0.9$.

\section{Differences in Lauric Acid Concentration Profile}

The difference in concentration of Lauric Acid profile can be seen in Table 2 below:

Table 2. Differences in Lauric Acid Concentration Profile

\begin{tabular}{cccc}
\hline Characteristics & $\begin{array}{c}\text { Before given VCO (\%) } \\
\text { Mean } \pm \text { SD }\end{array}$ & $\begin{array}{c}\text { After being given VCO (\%) } \\
\text { Mean } \pm \text { SD }\end{array}$ & p-value \\
\hline $\begin{array}{c}\text { Concentration profile of } \\
\text { Lauric Acid }\end{array}$ & $6,2 \pm 2,2$ & $6,6 \pm 2,4$ & 0,0001 \\
\hline
\end{tabular}

Based on Table 2, it is known that the average concentration of lauric acid profile after VCO was given was higher, namely $6.6 \pm 2.4$ while before VCO was given it was $6.2 \pm 2.2$. The results of statistical tests showed that there were differences in the concentration of lauric acid profiles before and after VCO was given.

\section{Differences in Increased Lauric Acid Levels}

The average increase in the concentration of lauric acid profile can be seen in Table 3 below: 


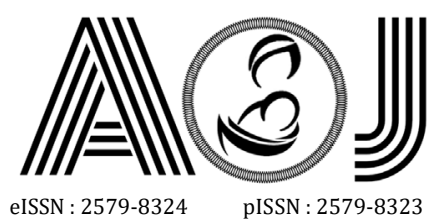

eISSN : 2579-8324

pISSN : 2579-8323

Table 3. Average Increase in Lauric Acid Concentration

\begin{tabular}{cc}
\hline Characteristics & $\begin{array}{c}\text { Increased (\%) } \\
\text { Mean } \pm \text { SD }\end{array}$ \\
\hline Lauric Acid Increase & $6,96 \pm 1,05$ \\
\hline
\end{tabular}

From the table above, the average increase in lauric acid levels ranges from $6.96+1.05$. From the results of the master table that has been made, it can be concluded that the highest increase was found in respondent number $5(9 \%)$ of the initial intake of breast milk and the lowest increase was found in respondent $11(5 \%)$ of the initial intake of breast milk.

\section{DISCUSSION}

Research has been conducted to determine the effect of giving VCO regularly for 2 weeks to see changes in lauric acid levels carried out on subjects. This is in accordance with the research plan to see lauric levels after consuming VCO for 2 weeks because at that time breast milk is already in the mature phase where breast milk in this phase has changed levels to a little fatty acid. The average age of the respondents in this study was $29.9 \pm 4.7$ years and the average parity was $2.7 \pm 0.9$. It is hoped that by giving VCO, lauric acid in mature breast milk is in a state of constant or increased levels.

The research subjects consisted of 17 respondents, all of which came from post partum care patients 5-8 days at the Rika midwife clinic in Andalas, Padang city. At Rika's midwife clinic, postpartum patients are patients who often control and are known to live in Padang. This is necessary to ensure that the patient can return to the clinic for control for the second breastfeeding. In this study, 17 research subjects were taken because it refers to the sample size according to Ouyang by using the sample size formula for experimental research which obtained a minimum sample size of 15 people and preparation if there were 2 people who dropped out. Each subject has given informed consent to take breast milk and study VCO consumption.

Subjects were women with a previous history of exclusive breastfeeding. In accordance with the inclusion criteria and the literature in this paper, breastfeeding is at least 6 months without other foods. This is because in exclusive breastfeeding, breastfeeding continues and the metabolism of fatty acids in breast milk is not disturbed.

The subject had no history of digestive disorders and had never had gastrointestinal surgery. The subject did not consume high-fat foods and did not consume other coconut oil products. This is asked to ensure that there are no abnormalities in the gastrointestinal tract, especially the intestines where food is absorbed.

Mother's Milk (ASI) is the best food produced by the breast glands, it contains all the nutrients needed for babies aged 0-6 months. In this study, the respondents were mothers who were actively breastfeeding and it seemed that the respondents were really 


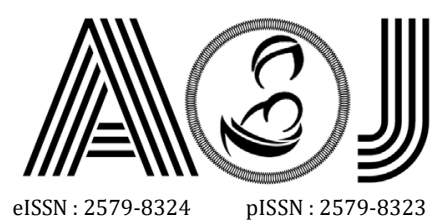

eISSN : 2579-8324
pISSN : 2579-8323
ANDALAS OBSTETRICS AND GYNECOLOGY JOURNAL

Address for Correspondence:

Editorial Room Andalas Obstetrics and Gynecology Journal, $3^{\text {rd }}$ floor of KSM of Obstetrics and Gynecology, RSUP DR. M. Djamil Padang, Jl. Perintis Kemerdekaan Padang, Sumatera Barat 25127

Website:

http://jurnalobgin.fk.unand.ac.id/index.php/JOE

breastfeeding their babies. Respondents whose breast milk was taken were mothers who had given birth before and had breastfed for +6 months, the statement was concluded from the history of childbirth and questions asked to the subject directly.

From the research results obtained, there is no significant correlation between the age of the respondents and the number of parity of the respondents. The number of parity is determined more than once to ensure respondents with the condition that they have been exclusively breastfed.

In the results of research conducted on 17 respondents, it was found that the average level of lauric acid in the respondent's breast milk increased after consuming VCO oil for 2 weeks. There was a difference in the average level of lauric acid before and after VCO was given $(p<0.05)$ with an average increase in concentration of $6.96 \pm 1.05$. This proves the theory presented by consuming VCO which is rich in lauric acid. Metabolism of lauric acid as a medium chain fatty acid that is rapidly metabolized in the body.

It was found that there was an increase in lauric acid in breast milk after consuming VCO for 2 weeks. This is due to the addition of lauric acid levels in breast milk by lauric fatty acids in the VCO itself. The fatty acids in VCO which are medium chains are metabolized quickly and directly in the liver and then directly distributed in breast milk. The addition of these fatty acids does not increase greatly because lauric acid is metabolized in the body and produced in breast milk remains within the limits of only a few percent.

According to international standards issued by the APCC (Asian Pacific Coconut Community) that the lauric acid content of VCO is $43-53 \%$. The highest fatty acid composition in virgin coconut oil is lauric acid which functions to provide nutrition and protect the body from infectious and degenerative diseases. ${ }^{51}$

It was found that a small amount of lauric acid was found in the mean of all breast milk at the time of the first intake with an average of below $10 \%$. After treatment in the form of respondents consuming VCO for 2 weeks as much as 3 spoons a day, there was a significant increase in lauric acid. This is related to Rina Astuti's research in 2014 which found an increase in the total volume of breast milk for 4 hours after giving VCO compared to the control group. This is due to the ability of VCO as an Anti-analgesia that provides a relaxation sensation so that it can increase breast milk. The same study also observed the effect of giving virgin coconut oil on fatty acids in breast milk where there was an increase in the content of lauric acid, capric acid and caprylic acid after 12 hours of VCO administration, and a significant increase in lauric acid, capric acid and caprylic acid also occurred in the week the fourth was $25.60 \%$, while in the fifth week there was a decrease in the fatty acids contained in breast milk because women did not consume VCO anymore. Here there is a difference in the increase in lauric levels between the research conducted by Rina and the researcher, this is because there may be differences in fatty acid metabolism in the body and distribution in breast milk. 


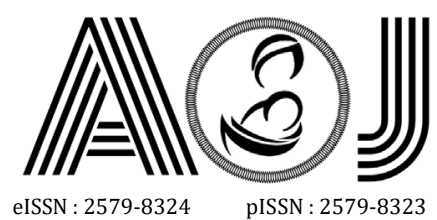

eISSN : 2579-8324
pISSN : 2579-8323

The breast milk obtained on the 5th and 6th day is transitional milk and the average fatty acid is below $10 \%$. This is in accordance with Nahrowi's 2015 study which stated that the average lauric level in breast milk at the beginning of labor was around $+6 \%$. This result is also supported by the research of Lien et al in 1997 and Innis et al in 1994. Lauric acid in VCO is the same in function and efficacy in breast milk in accordance with the Wibowo study in 2005.

The increase in lauric acid levels in this case is in accordance with Francois' research in 1998 with the consumption of VCO, there is also an increase in lauric acid levels in breast milk with significant achievements and studied in a short time. If you consume $40 \mathrm{~g}$ of coconut oil, it will increase the lauric acid content in milk over time. Lauric acid increased from $3.9 \%$ to $9.2 \%$ at 10 hours and $9.6 \%$ at 14 hours. However, in this study, the long consumption period was around 14 days and an increase of around $7 \%$ was found.

A study published in 1998 in the American Journal of Clinical Nutrition has shown that breastfeeding mothers who consume coconut oil and other coconut products, have significantly increased levels of lauric acid and capric acid in their breast milk. This study also showed a significant increase in lauric acid by excluding the addition of other coconut products.

Based on other research, storage and freezing of breast milk does not affect lauric acid levels. This is not very influential because the researchers used the IDAI ASI storage standard. The IDAI standard in the presenter's paper certainly does not affect the protein and fat levels contained in breast milk.

\section{CONCLUSION}

Based on the results of the study, it can be concluded that there is an effect of giving VCO coconut oil to increase in Lauric Acid levels in breast milk

\section{REFFERENCES}

1. Prapun $\mathrm{R}$, Cheetangdee $\mathrm{N}$ and Udomrati S. Faktor yang mempengaruhi niat ibu memberikan ASI eksklusif di Kelurahan Magersari, Sidoarjo. Jurnal Promkes. 2016; 4(1): 11-21.

2. Gunasekaran R et al. Maternal intake of dietary virgin coconut oil modifies essential fatty acids and causes low body weight and spiky fur in mice. BMC Complementary and Alternative Medicine. 2017; 17:79.

3. Bravi F, Wiens E, Decarli A, Pont AD, Agostoni C and Ferraroni M. Impact of maternal nutrition on breast-milk composition: a systematic review. Am J Clin Nutr. 2016;104:646-62. 


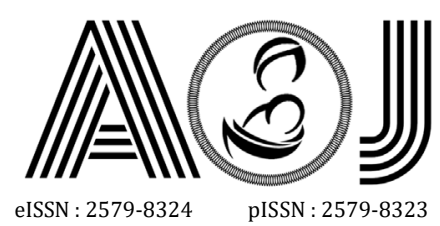

4. Astuti R, Sinaga SM and Putra EDL. Effect of taking virgin coconut oil to the breast milk secretion and inspection of medium chain fatty acids contain. Int.J. PharmTech Res. 2015;7(3): 481-487.

5. Walyani E. 2015. Perawatan kehamilan dan menyusui anak pertama agar bayi lahir dan tumbuh sehat. Yogyakarta : Pustaka Baru Press.

6. Pillay J, Davis TJ (2019). Physiology, lactation. https://www.ncbi.nlm.nih.gov/books/NBK499981/. Diakses pada 29 Februari 2020.

7. Martin CR, Ling P dan Blackburn GL. Review of infant feeding: key features of breast milk and infant formula. 2016; 8(5): 279.

8. Yao Y, Zhao G, Yan Y, Mu H, Jin Q, Zou X, et al. Milk fat globules by confocal Raman microscopy: Differences in human, bovine and caprine milk. Food Research International. 2016;80:61-69

9. Koletzko B. Human milk lipids. Annals of Nutrition and Metabolism. 2016;69:28-40

10. Gardner A, Rahman I, Lai C, Hepworth A, Trengove N, Hartmann P, et al. Changes in fatty acid composition of human milk in response to cold-like symptoms in the lactating mother and infant. Nutrients. 2017;9:1034

11. Palmeira P, Sampaio MC. Immunology of breastmilk. Rev Assoc Med Bras 2016; 62(6):584-593.

12. Pubchem (2020) . Lauric acid. https://pubchem.ncbi.nlm.nih.gov/compound/Lauricacid. Diakses tanggal 6 Maret 2020.

13. McCarty MF, DiNicolantonio JJ. Lauric acid-rich medium-chain triglycerides can substitute for other oils in cooking applications and may have limited pathogenicity. Open Heart. 2016; 3(2): e000467.

14. Widianingrum DC, Noviandi CT and Salasia SIO. Antibacterial and immunomodulator activities of virgin coconut oil (VCO) against Staphylococcus aureus. Heliyon 5. 2019; e02612.

15. Srivastava Y, Semwal AD and Sharma GK. Therapeutic, probiotic and unconventional food. Elsevier. 2018: 291-301.

16. Mulyani RI. 2014. Studi kandungan dan persentase daily value asam lemak esensial makanan Indonesia. [Skripsi]. Departemen Gizi Masyarakat. Fakultas Ekologi Manusia. Institut Pertanian Bogor. Bogor.

17. Fabian M. The properties of lauric acid and their significance in coconut oil. J Am Oil Chem Soc 2014; DOI 10.1007/211746-014-2562-7

18. Wood, J.D, R.I. Richardson, G.R.Nutc. A.V.Fisher, M.M. Campo, E.Kasapidou, P.R. Sherd, M. Enser. 2003. Effects of fatty acids on meat quality : a review. Meat Science $66: 21-23$. 


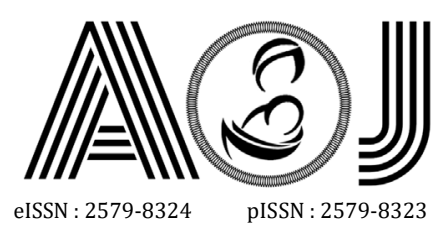

eISSN : 2579-832

Editorial Room Andalas Obstetrics and Gynecology Journal, $3^{\text {rd }}$ floor of KSM of Obstetrics and Gynecology,

19. Yamashita M, Kadona Y. 1982. Digestion, absorption and metabolism of medium-chain trigliserides. New food Ind. 24: 28-33

20. Pontoh J, Buyung NTN. Analisa asam lemak dalam minyak kelapa murni (VCO) dengan dua peralatan kromatografi gas. Jurnal IImiah Sains. 2011;11(2):274-81. 